M. Ulil Abshor

\title{
OTORITAS KEILMUAN GUS IZZA SADEWA DAN \\ MEDIA BARU \\ (Putra KH. Imron Jamil Jombang)
}

\author{
M. Ulil Abshor \\ UIN Sunan Kalijaga Yogyakarta \\ Email: ulilabshor91@gmail.com
}

\begin{abstract}
$T$

he study aims to uncovered the facts behind the scientific authority that was showed by Gus Izza Sadewa (the son of KH. Imron Jamil Jombang), who was only 15 years old and was able to present a scientific identity and sufism practices that was very beneficial. The author focuses on YouTube's new media as a shaping of scientific authority in the cyberculture world. The author analyzes the content analysis of some YouTube videos about Gus Izza. The content provided is manifested in aspects of contextual sufism. According to Heidi A. Campbell, there are 4 things that influence a religion or a text ideology, namely hierarchy (value), structure, ideology, and text. The results obtained from several segments of the hierarchy or values formed in the self of Gus Izza, he has Sufism and mature scientific authority, which can be proven by giving explanations about monotheism, the most important in looking for mursyhd-teachers, faith, actualizing worship that applied in daily life. All of those have the main orientation in the virtue ethics (akhlaq al-karimah).
\end{abstract}

Keywords: Scientific Authority, Contextual Sufism, and Youtube.

\begin{abstract}
Abstrak
$\mathrm{P}$

enelitian ini bertujuan mengungkap fakta dibalik otoritas keilmuwan yang dibangun oleh Gus Izza Sadewa (Putra KH. Imron Jamil Jombang), masih usia belia 15 tahun mampu menyuguhkan sebuah identitas keilmuwan dan sikap sufi yang bernilai tinggi. Penulis memfokuskan pada media baru Youtube sebagai pembentuk otoritas keilmuan di dunia cyberculture. Penulis menganalisis pada fokus analisis isi konten dibeberapa video youtube tentang Gus Izza. Kandungan isi yang diberikan mewujud dalam aspek tawasuf kontekstual. Otoritas menurut Heidi A. Campbell ada 4 hal yang mempengaruhi sebuah otoritas agama atau ideologi teks yakni hirarki (value), struktur, ideologi dan teks. Hasil yang diperoleh dari beberapa segmen hirarki atau value yang terbentuk pada diri Gus Izza, dia memiliki otoritas keilmuan tasawuf yang cukup matang dan dalam, bisa dibuktikan dengan memberi penjelasan tentang seputar tauhid, pentingnya mencari guru mursyid, keimanan, aktualisasi ibadah yang mewujud dalam keseharian. Dari kesemuanya itu memiliki orientasi yang pokok dalam pengamalan akhlaq al-karimah.
\end{abstract}

\section{Kata Kunci: Youtube, Otoritas Keilmuan, dan Tasawuf Kontekstual}


Otoritas Keilmuan Gus Izza Sadewa...hal. 167-182

PENDAHULUAN

Fenomena yang dapat dinilai secara ilmiah merupakan sebuah fakta (Tim Penyusun Kamus Bahasa Indonesia, 2008: 407), yang melatarbelakangi lahirnya sebuah otoritas dari publik figur. Sehingga tidak lepas dari peran struktur, paradigma, ideologi dan institusi ataupun lingkungan komunal yang membentuknya, hal ini banyak pula para tokoh masyarakat semisal kyai sebagai publik figur yang diyakini memliki otoritas keilmuwan yang mumpuni dalam menyampaikan dakwah, terutama dakwah yang bernilai teduh dan mendamaikan, sehingga tidak jarang mereka memiliki jama'ah yang jumlahnya idak sedikit baik jama'ah off air atau on fair.

Jama'ah yang begitu antusias dalam mengikuti setiap langkah dan pesan pesan dakwah dari publik figur menjadi bagian pengaruh kehidupan dalam membentuk sebuah karakter individual masyarakat, karakter yang mendorongnya menjadi lebih baik. Karena bagaimanapun otoritas mengacu pada wewenang yang diberikan secara sah kepada seorang karena didukung oleh sebuah peraturan atau norma yang berlaku di masyarakat. Artinya masyarakat mengetahui secara langsung nilai nilai keunggulan secara terbuka yang melekat pada diri seseorang (Hamid, 2011: 47; Subkhani Kusuma Dewi, 2016: 198).

Publik figur yang memiliki otoritas muncul dari tradisi kesucian, dipahami sebagai salah satu kharisma, sehingga menjadi kekuatan yang unggul di masyarakat (Heidi A. Campbell, 2012: 73). Publik figur yang oleh penulis sebut dalam penelitian ini adalah para kyai, pemuka agama, steak holder, baik kyai selebriti atau kyai non selebriti. Kesemuanya memiliki otoritas tertentu dalam menciptakan ciri khas atau karakter dakwahya. Dakwah yang dilakukan para kyai tidak hanya melalui saluran langsung (laring) off air, namun juga dari jaringan langsung (daring) melalui media baru sebagaimana penulis sebutkan youtube, facebook, twitter, instagram, dan bahkan telegram. Hal ini melihat perkembangan dakwah melalui media daring dan internet lebih efektif, secara struktur dan massif untuk dijangkau oleh kalangan masyarakat yang mayorits pengguna media sosial (Eva F. Nisa, 2018: 2).

Peran kyai dalam berdak'wah memiliki pengaruh kepada para audiens, masyarakat, karena dibentuk oleh otoritas keagamaan dan keilmuwan yang memadai secara simultan. Namun dalam anasir penulis, otoritas seorang putra kyai yang dipanggil Gus juga memiliki otoritas keilmuwan yang cukup massif dan cukup kapabel sebagaimana orangtuanya (baca: kyai).

Otoritas di sini perlu diketahui sebagai upaya memahami lebih jauh konsep otoritas tersebut, penulis tidak mengesampingkan pembentukan konsep Weber tentang tiga tipe otoritas (wewenang): tradisional, rasional-legal, dan kharismatik. Tipe-tipe Weber tersebut dikaitkan dengan bentuk-bentuk aksi sosial dan hubungan-hubungan sosial yang menjadi ciri khas berbagai kelompok masyarakat. Memang tipologi yang dirumuskan Weber diletakkan dalam konteks kepemimpinan (politik). Namun, karena kepemimpinan tidak dapat dilepaskan dari otoritas, maka tipologi ini juga bisa kita adaptasi dalam melihat konstruksi otoritas keagamaan. Otoritas yang diusung oleh weber tidak menjadi bagian analisis penulis untuk melihat model otoritas yang dibangun oleh Gus Izza Sadewa, namun penulis ingin mengungkap 
dan menguraikan kerangka otoritas yang digagas oleh Heidi A. Campbell yaitu meliputi hirarki kepemimpinan, struktur komunitas, ideologi keyakinan dan teks ajaran yang mempengaruhinya (April Carter, 1979: 54-56).

Otoritas sebuah publik figur yang menjadi basis kompetensi, ingin penulis kupas dan uraikan dalam bingkai media daring yaitu youtube. Peran youtube telah memperkenalkan Gus Izza dalam kancah dakwah cyberculture. Penulis mengambil sampel media baru youtube dalam mengungkap otoritas keilmuwan seorang Gus. Di mana fenomena otoritas adalah peran keilmuwan yang dibangun Gus Izza melalui pengajian lewat youtube dalam rangka menciptakan otoritas struktural, apakah otoritas keilmuwan yang dibangun Gus Izza benar benar memiliki latar belakang pendidikan yang kuat atau ada unsur lain sehingga kemudian melahirkan keilmuwan yang mumpuni dan bagaimana dalam mewujudkan otoritas keilmuwan tersebut tentu penulis menganalisis dengan memfokuskan pada aspek video youtube yang tersebar di beberapa konten yang tersedia pada 4 macam fragmen. Penjelasan akan diuraikan dibawah ini dengan pendekatan media baru atau Cyberculture yakni media daring youtube (Lev Manovich, 2003: 2). Pendekatan media baru berupa youtube menjadi landasan penelitian sebagai titik tekan dalam mengenalkan tokoh yang memiliki otoritas keilmuwan yang kuat dalam rangka sebagai dakwah yang lebih transformatif di era perkembangan teknologi (Ibnu Hajar, 2018: 95).

Dalam analisis ini penulis mencoba memetakan hal apa yang perlu diungkap dalam menjelaskan otoritas keilmuwan yang dibangun oleh Gus Izza, lebih pada persoalan karakteristik yang membentuk dn memiliki peran yang kuat di dunia sosia media, utamanya youtube antara lain. Pertama, sekelumit mengenai identitas Gus Izza. Kedua, Otoritas keilmuwan. Ketiga, youtube sebagai media baru dalam mewujudkan otoritas keilmuwan.

\section{SEKILAS TENTANG GUS IZZA SADEWA \\ Kelahiran}

Gus Izza nama panggilan, nama lengkapnya Muhammad Izza Sadewa lahir di Jombang 28 April 2001 putra seorang kyai kondang KH. Imron Jamil. KH. Imron Jamil ini sering mengisi ceramah di berbagai kota baik Jawa Timur, Jawa Tengah maupun luar jawa. Mengenai riwayat pendidikan Gus Izza yang penulis dapatkan dari berbagai sumber internet dan teman temannya. Sekilas pendidikan yang dilalui oleh Gus Izza hanyalah sampai tingkat MI Bahrul Ulum Jombang, saat masih MI kemudian memutuskan mondok Ngasinan di Jember lalu dilanjutkan mondok di kwagean Ponpes Fathul 'Ulum Kencong Kepung Kediri asuhan KH. Abdul Hannan Ma'shum (Video Youtube 14 Juni 2017).

Di Pondok ini Gus Izza sering belajar ilmu alat yakni nahwu sharaf kepada Gus Muhammad Muslim putra pertama KH. Abdul Hannan Ma'shum (Video Youtube, 15 Juni 2017). Dia hanya ngaji di kwagean. Walaupun jadwal ngisi ceramah sebagai pengganti ayahnya kyai Imron Jamil. Gus Izza masih tetap menyempatkan waktunya untuk belajar ke pondok pesantren kwagean Fathul Ulum asuhan kepada Kyai Hannan Maksum dan para putra putra kyai Hannan sekaliGus kepada para ustadz pondok pesantren lainnya.

Dilihat dari latar belakang keilmuwan Gus Izza dengan umur yang belum genap dewasa, masih menginjak remaja tentu sulit mencoba mendalami 
Otoritas Keilmuan Gus Izza Sadewa...hal. 167-182

sebuah keilmuwan yang mumpuni, level tingkat keilmuwan yang diperoleh oleh para masyaikh, terlebih dalam ilmu tasawuf, keilmuwan para sesepuh dalam menempuh perjalanan menuju Tuhan dibutuhkan waktu yang lama dan kesungguhan luar biasa secara tekun, Riyadhah, malakukan perjalanan suluk dengan dibimbing oleh guru mursyid.

Sejalan dengan konsep tazkiyatun nafs (penyucian diri atau jiwa) guna memperoleh suatu tingkatan dalam meraih derajat kesempurnaan (Insan Kamil), manusia sempurna yaitu pertama yang harus dilakukan dengan cara Takhalli/ Zero Mind Process mengosongkan diri dari kejahatan dan keburukan. Kedua dengan cara Tahalli/Character Building menghias diri dengan berperilaku baik, berfikir yang baik dan ketiga dengan cara Tajalli/Got Spot kondisi dimana kualitas Ilahiyah dalam dirinya termanifestasikan atau teraktualisasikan dalam diri manusia (Hasyim Muhammad, 2000: viii).

Namun kali ini penulis mengetahui sendiri dari salah seorang jama'ah bahwa keilmuwan Gus Izza itu dibentuk dan diinstal atau ditanamkan bil ghaib langsung oleh guru ayahnya yaitu Syaikh Abdul Jalil Tulungagung Mursyid thariqah Syazdiliyah. Jika merujuk ke dalam sumber dari Muslimmoderat menunjukkan bahwa secara panggung ia sangat mahir dan menguasai dan mampu bikin gelak tawa yang khas (Muslimmoderat.net, 15 April, 2018).

\section{Tradisi Pesantren di Keluarga}

Tradisi ilmu menjadi akar rumput (baca: keilmuwan) yang sangat signifikan dalam membentuk kepribadian seseorang, tak terkecuali dalam diri Gus Izza, Gus Izza dilahirkan di tradisi yang lingkungan tradisi tersebut memberinya pelajaran yang tak sedikit. Tradisi yang dijunjung dilingkungan pesantren memperkenalkan beberapa prinsip 1). Ingat Allah ( dzikrullah ) 2). Usahakan selalu suci 3). Sebarkan manfa'at dan hindarkan madlorot 4). Laksanakan kewajiban Agama sesuai aturan 5). Tanya bila tidak tahu (Profil pondok pesantren Kyai Mojo Jombang, 27 Mei, 2017). Kelima prinsip yang dicanangkan ini memberi kekuatan yang teguh dalam menumbuhkan kekuatan otoritas pada diri seorang Gus Izza.

Pesantren yang didirikan oleh orangtuanya Kyai Imron Jamil, diberi nama Kyai Mojo, nama Kyai Mojo itu atas usulan gurunya KH. Abdul Jalil Mustaqim. Namun awal mula berdiri pesantren Kyai Imron Jamil belum memiliki nama khusus hanya dikenal sebutan pesantren kyai Imron Jamil. Di samping nyantri dan sehabis pulang dari perantauan berguru kepada Romo $\mathrm{KH}$. Djamaludin Ahmad, Beliau sempat mengenyam sekolah formal hingga lulus doktorandus dari perguruan tinggi di STIT BU.

Sebenarnya pada tahun 1994 kyai Imron Jamil sudah punya santri yang berjumlah 8 santri berasal dari berbagai daerah atau kota seperti Tuban, Lamongan, Blora, Tulungagung, dan lain-lain. Santrisantri itu pun kebanyakan kuliah sekaliGus ngawulo (mengabdi) pada kyai Imron Jamil. Walaupun saat itu Kyai Imron juga belum memiliki rumah sendiri hanya ngontrak di rumah sebelah mushola Authon peterongan Jombang, setelah tinggal selama kurang lebih 2 tahun di rumah tersebut bersebelahan dengan warung Mak Ti (sekarang).

Pesantren ini karena seiring dengan banyaknya santri yang berminat belajar padanya, beliaupun mempuyai niatan untuk membeli tanah sekaliGus mendirikan rumah sendiri. Pada tahun 1997/1998 beliau 
mencari tanah kosong yang dijual. Singkat cerita beliau menemukan tanah yang berdiri rumah kosong, dan cenderung mistis atau angker (mengerikan). Konon rumah itu sangat angker dan tak ada satu pun orang berani membelinya. Akhirnya Kyai Imron datang dan mengajukan diri untuk membeli tanah itu. Dengan biaya yang terjangkau Kyai Imron Jamil pun membeli tanah seluas 16x30 m2 yang letaknya sebelah timur jalan raya $\mathrm{KH}$. Wahab Chasbullah tambak beras Jombang Lebih tepat lagi $50 \mathrm{M}$ sebelah utara lapangan tambak beras.

Di situlah Kyai Imron membangun kediamannya dan memboyong semua santri-santrinya ke rumah itu. Semakin lama peminatnya sekaliGus anak anak muda yang ingin belajar kepadanya pun kian bertambah. Hal itu membuat beliau berfikir dan berniat mendirikan pondok/asrama. Beliaupun akhirnya sowan pada guru mursyidnya (KH. Abdul Jalil Mustaqim) guru mursyid tarekat syadziliyah atas izin syeih Abdul Jalil akhirnya Kyai Imron membangun pondok di sisi kanan kiri rumahnya.

\section{PEMBAHASAN}

\section{Otoritas Keilmuwan}

Otoritas keilmuwan seseorang ditentukan oleh lingkungan sosial yang mempengaruhinya sehingga membentuk karakter dan kepribadian yang unggul, sebagai istilahnya weber yang dikutip oleh Amartuti adalah kharisma, kharisma yang menjadi publik figur, publik figur yang berilmu dan berwibawa (Amiartuti, 2012: 130). Seseorang yang memiliki otoritas, tidak lepas dari tradisi yang membentuknya sehingga dengan tradisi tersebut setidaknya mampu mendorongnya untuk memperoleh legitimasi yang unggul baik lingkungkan keluarga atau masyarakatnya.
Dalam Encyclopedia Alfabet of Social Science otoritas didefinisikan sebagai kapasitas, bawaan atau diperoleh untuk melaksanakan pengaruhnya terhadap kelompok (Michaels, 2011: 304). Pendapat lain mengatakan bahwa otoritas bukanlah kapasitas tetapi hubungan ilmu dan kewibawaan. Otoritas keilmuwan yang dibentuk oleh lingkungan terutama keluarga memiliki signifikansi, tatkala otoritas keilmuwan tersebut bersentuhan dengan media online sebagaimana internet, youtube, instagram dan lain sebagainya. Penulis mencoba memetakan model otoritas kelimuwan yang dibangun oleh Gus Izza tersebut dari apa yang diusung oleh Heidi A. Campbell. Otoritas yang melahirkan suatu pandangan yang otentik dan original pada sebuah ranah keilmuwan, memengaruhi pola pikir masyarakat yang hidup di era teknologi, karena dengan adanya teknologi segala hal yang memberi pengaruh pada konsumen pengguna media sosial memperkuat sebuah otoritas keagamaan dengan cara yang khas (Jajat Burhanudin, 2012: 366)

\section{Hirarki}

Otoritas keilmuwan yang menjadi hirarki terletak pada aspek otoritas tradisional. Menurut weber otoritas tradisional ini merupakan sebuah kepatuhan atau adat istiadat karena adanya rasa hormat terhadap pola tatanan lama yang telah mapan (George P. Hansen, 2001: 102). Kepatuhan yang dilakukan dalam konteks ini lebih mengedepankan bentuk rasa penghargaan dan penghormatan terhadap tradisi keilmuwan yang membentuknya. Hal ini tentu berkaitan dengan tradisi di mana peran seorang pemimpin, sebutlah seorang kyai dalam kerangka yang penulis angkat peran Kyai Imron Jamil yang sekaliGus 
Otoritas Keilmuan Gus Izza Sadewa...hal. 167-182

menjadi musryid Tarekat Sadhiliyah membentuk sisi kelimuwan yang mumpuni, sehingga hal ini benar benar berpengaruh dalam karakter dan keilmuwan yang diemban oleh Gus Izza.

Kyai Imron Jamil merupakan sosok kyai tampan dan gemilang pikirannya asal Jombang sekitar tahun 1991 Masehi beliau mulanya mengontrak rumah untuk ditempat tinggali bersama istri tercinta (ibu nyai $\mathrm{Hj}$. Dra. Titi Maryam) di sebuah dusun kecil di tengah-tengah antara Tembelang dan Tambakberas, tepatnya di petengan tembelang Jombang. Selepas pulang mondok dengan KH, Djamaludin di Bahrul Ulum kemudian melanjukan kuliah di STIT BU hingga lulus. Dari beliau lahirseorang anak muda bernama Muhammad Izza Sadewa yang dikenal memiliki kedalama ilmu tasawuf tingkat tinggi (wawancara dengan penggemar Gus Izza, 27 Mei, 2018).

Peran Kyai Imron Jamil sangat kuat dalam membentuk kepribadian putra putranya di keluarga beliau, lagi pula beliau Kyai Imron Jamil memiliki mursyid Tareqat Syadiliyah KH. Abdul Jalil Mustaqim Tungangung. Hal Ini yang kemudian dalam pandangan penulis memiliki karakter kokoh, ini dibuktikan dengan banyak segmen hasil pengajian yang seringkali disampaikan mengandung nilai tasawuf dan kehidupan dalam bermasyarakat. Bahkan setiap pengajian kitab tafsir munir karya Syaikh Nawawi al-Bantani dan kitab al-Hikam Ibn 'Athaillah as-Sakandari. Setiap ba'da shubuh dan ba'da asyar selalu disiarkan melalui radio dengan channel FM 95.

Ini menunjukkan karakter pemimpin sekaliGus orang tua yang tidak hanya melahirkan akan tetapi menyebarkan akar tradisi otoritas keilmuwan tasawuf, sehingga hal ini yang menimbulkan pengaruh besar di dalam keluarga, terutama Gus Izza. Sebab bagi Gus Izza saat hendak ngisi pengajian dalam setiap ceramahnya yang sekaliGus menggantikan orang tuanya Kyai Imron Jamil, bukan kemauanya sendiri akan tetapi memperoleh titah dan mandat dari orang tua Kyai Imron Jamil (Video Youtube, 27 Mei 2017).

Dari kategori-kategori hirarki keilmuwan yang terjadi dalam tradisi otoritas keagamaan, menjadi akar yang menunjukan peran seorang pemimpin yang berwibawa, tergolong bagian yang penuh arti dalam mewujudkan tatatan sosial masyarakat yang komplek. Tatanan sosial masyarakat menjadi bagian yang tidak bisa dihindari dalam membentuk realitas sosial.

\section{Struktur}

Struktur sosial dan keluarga kerabat yang membentuk seseorang selalu memiliki pengauh sikap dan perilaku dalam kehidupan sehari hari. Struktur sosial yang dimaksud dalam pandangan ini adalah komunitas, rumusan praksis dalam kehidupan sosial dan organisasi kelembagaan (Heidi A. Campbell, 2012: 7374). Atau para ahli sosial mengatakan hubungan antar individu, kelompok dan organisasi dalam kemasyarakatan sehingga terbentuknya nilai nilai atau norma masyarakat. Hal ini meliputi status, peran yang terdapat di dalam satuan sosial, adanya ekonomi, politik, hukum, sosial dan saling mempengaruhi.

Berhubung setiap manusia anggota dari masyarakatnya atau keluarga maka struktur sosial yang dibentuk oleh pemimpin yang terdapat dikeluarga sebagaimana Kyai Imron Jamil, memberi selubung nilai dan norma berupa sikap welas asih, sikap dan karakter yang dibentuk karena adanya dua unsur yang melatarbelakanginya. Pertama, individu menjadi bagian yang membentuk 
M. Ulil Abshor

masyarakat atau keluarga, namun jika indvidu tidak ada di dalam lingkungan keluarga maka tidak terbentuk struktur sosial yang mempengaruhi masyarakat. Individu perseorangan yang dibentuk oleh lingkungan keluarga sebagaimana Gus Izza yang hidup di lingkungan keluarga yang mengenal ilmu tasawuf membentuk struktur sosial di masyarakat. Hal ini bisa dilihat peran Kyai Imron Jamil di saat beliau sedang berhalangan hadir untuk mengisi acara pengajian di berbagai kota, sedangkan yang bertugas sebagai pengganti adalah putra terakhir yaitu Gus Izza untuk mengisi pengajian sebagaimana ayahnya karena Kyai Imron Jamil melihat potensi yang besar pada diri seorang Gus Izza putranya ini ketimbang putra-putri yang lainnya. Ditunjukanya Gus Izza sebagai badal, tidak serta merta asal tunjuk saja namun melalui istikharah, atas dasar itulah yang kemudian beliau baru memperbolehkan Gus Izza menjadi pembicara sebagai ganti ayahnya (video youtube 17 Juli 2017).

Kedua, interaksi yang cukup intens dalam lingkungan keluarga membentuk struktur sosial dalam masyarakat, struktur sosial ini dimaksud menjadi wadah otoritas seorang Gus Izza dalam menyampaikan beragam dakwah dan isi ceramahnya. Isi ceramah atau konten menjadi faktor yang utama dalam menentukan sesorang memiliki kredibiltas keilmuwan yang mumpuni atau tidak. Dari latar belakang tersebut tentu penting mengetahui fungsi dari struktur sosial yang terjadi di masyarakat (Joan Gita Purwasih dkk, 2009: 64). Interaksi bisa dikaitkan tidak hanya sekedar ngobrol namun pada semacam intensitas dalam membentuk kebiasaan, laku, komunikasi, belajar dan orientasi hidup lebih diprioritaskan untuk selalu menuju kepada Allah.
Struktur sosial yang dibentuk dilingkungan keluarga atau lembaga memiliki aneka macam fungsi yang bisa membedakan antara individu satu dengan individu yang lain, antara organisasi satu dengan organisasi yang lain, antara lain. Struktur sosial sebagai penegas identitas, identitas seorang Kyai Imron Jamil dan Gus Izza sangat memiliki relasi yang jelas sebagai pribadi yang dibesarkan di lingkungan pesantren dan tradisi keagamaan yang kuat utamanya dalam hal thariqat dan tasawuf. Fungsi kedua yakni sebagai kontrol adanya persoalan yang terjadi di lingkungan keluarga dan masyarakat bahwa semua yang dilakukan itu bukan atas dorongan atau inisiatif dari dirinya sendiri, namun adanya kontrol dari keluarga sebagai doa yang terselubung di dalamnya. Ada beberapa unsur yang membentuk sebuah struktur sosial antara lain, pertama. Perasaan solidaritas solidarity feeling dari anggota keluarga di mana keluarga sangat berpengaruh dalam membentuk tradisi pemikiran dan keilmuwan seseseorang. Kedua, cita cita purpose dari keluarga untuk mewujudkan suatu tradisi religius atau agamis dengan beragam aktivitas laku spritual. Ketiga, kedudukan seorang publik figur ayah yang sangat membentuknya Kyai Imron Jamil. Keempat, nilai atau norma sebagai pedoman hidup dalam tradisi keluarga. Kelima, pengetahuan dan keyakinan yang dianut oleh anggota keluarga berupa tradisi tasawuf yang ketat. Ketujuh, kekuasaan atau sebagai pimpinan pesantren dan pemimpin keluarga memberi arahan dalam merumuskan prinsip hidup seorang anak. (Charles Loomis, 1960: 60).

\section{Ideologi}

Ideologi merupakan seperangkat gagasan atau pemikiran yang berorientasi pada tindakan yang tersistem secara teratur 
Otoritas Keilmuan Gus Izza Sadewa...hal. 167-182

(Satrapratedja, 2003: 45). Namun konsep ideologi tersebut intinya nilai-nilai yang dijadikan landasan seseorang untuk memahami sesuatu dalam menentukan sikap dan tindakan yang teratur. Ideologi yang terjadi dalam sebuah keluarga menentukan landasan berfikir dan bertindak secara sosial dalam memahami dan menafsirkan sesuatu di dunia. Ideologi yang dibentuk oleh Kyai Imron Jamil dari sebuah tradisi pesantren yang kemudian membentuk cara berfikir ideologis yang ditentukan oleh para guru, kyai-kyainya selama mengenyam pendidikan pesantren. Sehingga tak jarang apabila ideologi yang dibentuk dalam keluarga berpengaruh besar dalam mewujudkan nilai yang dipahami oleh Gus Izza.

Ideologi pun mampu menjadi motivasi hidup yang berperan secara signifikan dalam menentukan tindakan kongkrit manusia. Ideologi yang berpengaruh dalam pemikiran dan keilmuwan Gus Izza tak lepas dari peran Kyai Imron jamil dalam mempengaruhi realitas kehidupan keluarga, konon keilmuwan Gus Izza yang berorientasi dalam bidang sufi atau tasawuf, ilmu yang disampaikan oleh Gus Izza ternyata sudah diinstal oleh guru dari ayahnya yaitu $\mathrm{KH}$. Abdul Jalil Mustaqim. KH. Abdul Jalil Mustaqim merupakan mursyid thoriqah Syadziliyah di pesantren PETA (Pesulukan Thoriqah Agung). Bahkan Kyai Jalil Mustaqim yang membidani munculnya sebuah nama pesantren Mojo.

Gagasan atau prinsip keyakinan yang dijadikan pedoman dalam lingkungan keluarga mempengaruhi setiap individu yang terlibat di dalamnya. Gagasan yang dimaksud di sini adalah gagasan berupa pengetahuan dan ilmu yang dimiliki oleh seorang kyai Imron Jamil setidaknya menemui akar persoalan yang membentuk lingkungan dan tujuan dalam hidup, apalagi identitas yang disandang kyai Imron Jamil adalah seorang kyai yang 'alim terutama dalam bidang tasawuf untuk mendorong dirinya dalam mendidik dan mempengaruhi kondisi keluarga. Sehingga tidak dipungkiri kepribadiaan lingkungan keluarga ditentukan oleh struktur dan identitas ke 'diri'an nya kepada Allah. Maka pengaruh kyai Imron Jamil dalam diri seorang Gus Izza nampak dari setiap segmen video yang diunggah oleh beberapa penggemar atau jama'ahnya (Video Youtube, 27 Mei, 2017).

\section{Teks}

Teks yang membentuk otoritas keilmuwan seseorang adalah al-Qur'an, sunnah. Kedua sumber tersebut menjadi resepsi seseorang dalam menentukan perilaku dan keilmuwan seseorang yang melingkupinya. Keilmuwan seseorang ini yang membentuk otoritas keagamaan pada diri setiap masyarakat atau keluarga. Teks al-Qur'an yang dijadikan legitimasi merupakan usaha yang dilakukan (K. Bertens, 1995: 23). Teks al-Qur'an yang dijadikan landasan dalam muwujudkan prinsip dalam hidupnya makna dan tafsir yang identik dengan dunia tasawuf, jadi tradisi yang sering digelar oleh Kyai Imron Jamil yaitu penajian Tafsir al-Munir Marah Labid karya Syaikh Nawawi al-Bantati dan Ngaji al-Hikam (Video Youtube 18 Juni 2017).

Kedua kitab tersebut menjadi sumber otoritaf dalam mewujudkan nilai nilai prinsip hidup dalam beribadah kepada Allah. Jadi secara teks acuan yang digunakan bacaan dan fokus ilmu yang digeluti adalah tasawuf amaliyah. Konteks tasawuf amaliyah ini cenderung bergerak pada wilayah praktis sehingga pengajian 
kitab al-Hikam berorientasi pada pengamalan batin dan meningkatkan ketauhidan dan keimanan kepada Allah Swt. Hal ini menjadi aktivitas keseharian yang mewujud dalam sendi-sendi kehidupan Gus Izza.

Tasawuf amali ini membentuk suatu afirmasi terhadap aspek ibadah yang terinisiai oleh tradisi thariqat, sebagaimana Ibnu 'ajibah menjelaskan bahwa perkembangan tasawuf pada mulanya berawal dari tradisi individual personal, mulai menampakkan secara institusional thariqah atau Islamic order terdiri dari hirearki Shaik, Murid, dan al-'Ahd (Ris'an Rusli, 2013: 184). Selama ini Gus Izza menjadi bagian agent dari seorang guru yang mengamalkan thariqah Syadziliyah yang menitik beratkan pada persoalan keimanan dan akidah Islam dalam berdakwah.

\section{Media Baru dan Youtube Media Baru}

Gus Izza menjadi idola baru bagi kaum hawa. Mereka yang mengaguminya melihat keilmuwan yang ditampilkan di beberapa segmen videonya ia sering berkata bahwa rumusnya orang hidup itu harus iman, tampan dan mapan. Ketiga nilai dan prinsip hidup yang ia pegang tak lepas akan adanya usaha untuk memberi stimulus yang menarik dan provokatif bagi kalangan anak muda. Mereka hampir semua menginginkan menjadi pemuda yang berkualitas dan mau belajar yang lebih dalam lagi. Terutama memprovokasi para jama'ah khususnya yang ingin berdzikir secara lama, tenang dan mantap/dalam dengan penuh penghayatan. diperlukan suatu media yaitu Tariqah (Jalan Suluk kepada Allah) dalam mendekatkan diri kepada Allah (Sesi Video Youtube awal kali ceramah di Trenggalek 17 Juni 2017).

Media adalah segala sesuatu yang dapat menyalurkan informasi dari sumber informasi kepada penerima informasi. Manfaat media adalah memudahkan sesorang untuk memperoleh sesuatu yang di cari yang biasanya kita cari langsung dari tempatnya kini sudah tidak begitu lagi, kita bisa memesan barang melalui fasilitas internet ataupun menghubungi customer service, juga bagi mahasiswa dan pelajar adalah penyampaian materi pembelajaran dapat diseragamkan, proses pembelajaran menjadi lebih jelas dan menarik, proses pembelajaran menjadi lebih interaktif, efisiensi dalam waktu dan tenaga, meningkatkan kualitas hasil belajar siswa, memungkinkan proses belajar dapat dilakukan di mana saja dan kapan saja, menumbuhkan sikap positif siswa terhadap materi dan proses belajar serta mengubah peran guru ke arah yang lebih positif dan produktif. Sedangkan "Baru" adalah sesuatu yang dapat menciptakan inovasi, ataupun perubahan yang dapat melahirkan sesuatu yang sangat diinginkan orang (Rudy Setiawan, 2013: 361).

Media baru menjadi salah satu alat yang digunakan untuk menyebarkan konten dakwah sebab di era internet ini, jenis media sosial online sangat beragam. Salah satunya yang paling populer adalah YouTube. YouTube adalah sebuah situs web video sharing (berbagi video) populer dimana para pengguna dapat memuat, menonton, dan berbagi klip video secara gratis. Umumnya video-video di YouTube adalah klip musik (video klip), film, TV, serta video buatan para penggunanya sendiri sebagaimana video dakwah.

Media sosial YouTube digemari oleh masyarakat untuk berbagai macam sarana. Baik untuk sekedar melihat video atau pun mengunggah video kedalam YouTube. YouTube sendiri memiliki banyak manfaat, diantaranya adalah untuk mencari film, melihat musik, video terbaru, dan lain 
Otoritas Keilmuan Gus Izza Sadewa...hal. 167-182

sebagainya. Tidak lepas dari itu Youtube juga memiliki kekurangan misalnya kurang penyaringan antara video yang mencerminkan citra negatif karena untuk pengambilan dan mengunggah dalam bentuk video tidak ada batasan khusus jadi masyarakat dapat secara bebas mengunggah video dari YouTube. Media sosial ini sangat menarik untuk dibahas karena banyak hal yang menjadi pro dan kontra pada situs ini.

Banyak masyarakat yang beranggapan bahwa YouTube sebagai sarana penyaluran bakat, namun adapula dari situs ini sebagian masyarakat memanfaatkannya sebagai ajang kreativitas. Persepsi orang mengenai media sosial YouTube berbedabeda karena fungsi yang paling utama dalam media ini adalah mengaplikasikan suatu objek agar dapat disaksikan oleh para pengguna media tersebut. Dari media sosial berupa youtube ini munculnya tren idola yang jika menginginkan ustadz atau penceramah yang ingin didengar. Maka tinggal searching, cari judul yang sesuai dengan keinginan, langsung bisa mengakses secara cepat dan dapat menggali informasi yang dibutuhkan.

\section{Youtube}

Youtube didirikan oleh Chad Hurley, Steve Chen dan Jawed Karim mantan karyawan Paypal pada februari 2005. Youtube merupakan media baru atau bisa disebut web video sharing (berbagi video) yang populer dimana para pengguna dapat memuat, menonton, dan berbagi klip video secara gratis (Yolanda, Sandra \& Andre, 2018: 59). Perkembangan teknologi informasi termasuk youtube tidak hanya mampu menciptakan masyarakat dunia global, namun secara materi dapat mengembangkan ruang gerak kehidupan baru bagi masyarakat. Tanpa disadari, komunitas manusia telah hidup dalam dua dunia kehidupan, yakni kehidupan masyarakat nyata dan masyarakat maya (cyber community). Masyarakat nyata ialah sebuah kehidupan masyarakat yang secara indrawi dapat dirasakan sebagai sebuah kehidupan nyata, hubungan-hubungan sosial sesama anggota masyarakat dibangun melalui pengindraan. Dalam masyarakat nyata, kehidupan manusia dapat disaksikan sebagaimana apa adanya.

Kehidupan masyarakat maya merupakan suatu kehidupan masyarakat manusia yang tidak dapat secara langsung diindera melalui penginderaan manusia, namun mampu dirasakan serta disaksikan sebagai sebuah realitas. Pembentukan kelompok-kelompok masyarakat dalam dunia maya, tentunya terdiri atas individuindividu maya. Individu tersebut memiliki aspek yang beragam baik dari segi material ataupun immaterial. Keberagaman aspek tersebut turut mendapatkan fasilitas dunia maya. Mengingat dunia maya sebagai media sosial online yang sangat memungkinkan sosialisasi antar individu atau kelompok secara maya. Bahkan sebagai sarana dakwah yang memiliki kekuatan otoritas yang dibentuk oleh media baru yaitu Youtube (Dominic Strinati, 2007: 5).

Youtube menjadi idola bagi siapa saja yang mengaksesnya sehingga apapun yang diproduksi oleh suatu media utamanya youtube akan diterima oleh publik sebagai suatu nilai, dalam hal ini nilai kebudayaan. Kekuatan media dalam hal ini tidak lain adalah dalam mengkonstruksi realitas media yaitu sebuah realitas yang dikonstruksi berdasarkan sistem yang direkayasa oleh media tersebut dengan tujuan salah satunya adalah meraih keuntungan finansial dari publik yang mengkonsumsi semua jenis komoditi yang ditawarkan. Dalam 
perspektif industri budaya, "bahwa budaya populer adalah budaya yang lahir atas kehendak media".

\section{Gus Izza dalam Bingkai Otoritas Keilmuwan Tasawuf}

Penulis perlu menelusuri lebih jauh lagi terkait segmen video yang diunggah di Youtube. Keilmuwan seseorang ditentukan oleh kepada siapa belajar, siapa yang mengajari, pengaruh terhadap audiens (baca: jama'ah), pengetahuan yang dimiliki. Pengaruh terhadap audiens bagi penulis tidak hanya ditentukan oleh kehadiran secara langsung dan bertemu. Namun jama'ah online yang seringkali melihat beberapa segmen video juga memiliki pengaruh besar terhadap para pendengar yang setia jadi pendengar isi ceramahnya Gus Izza. Otoritas tidak hanya ditentukan oleh audiens yang mendengarkan video lewat youtube, namun juga ditentukan karena adanya rating dan jumah penonton dan seringkali diunggah beberapa kali.

Dari beberapa ceramah yang diunggah di Youtube penulis hanya mengambil 4 video dengan durasi waktu 40 menit hingga sampek 1 jam lebih 6 menit. Namun sebetulnya video tentang Gus Izza dari bergama jenis dan karakter sudah banyak, akan tetapi video dengan pengajian dan ceramah yang dilakukannya oleh Gus Izza yang personal hanyalah ada 4 macam video. Dari 4 macam video tersebut penulis penting mengulas pengaruh dari para audiens sehingga nilai otoritas dari Gus Izza tetap utuh bahwa yang disampaikan ada unsur ideologi dan gagasan yang mempengaruhinya. Ketentuan otoritas karena adanya "kesinambungan" hubungan media baru dan otoritas keagamaan dari beragam rentetan dan serangkaian keilmuwan yang dibentuk oleh tradisi (Heidi A. Campbell, 2012: 78).
Video youtube pertama dan viral yang diunggah oleh akun Kurnia FM pada tanggal 26 April 2017 dengan judul "Pengajian Lucu Putra Kyai Imron Jamil Jombang)" dengan durasi waktu 01:06:07 dan sudah ditonton lebih dari 2.207.629 kali dengan subscribe 1,6 ribu. Video kedua viral yang diupload oleh akun Ceramah pada tanggal 17 Juli 2017 dengan judul "Ceramah Gus Izza Sadewa dari Jombang” dengan durasi waktu 53:14 dan sudah ditonton lebih dari 30.600 kali dan subscribe 1,4 ribu. Video ketiga viral yang diupload oleh akun Kang Zahid pada tanggal 29 Desember 2017 dengan judul "Sangar! Gus Izza Sadewa Ceramah" dengan durasi waktu 55:23 dan sudah ditonton lebih dari 38.303 kali dan subscribe 1,6 ribu. Video keempat viral yang diunggah oleh akun Kurnia FM pada tanggal 10 Mei 2018 dengan judul "Pengajian umum bersama Guz Izza" dengan durasi waktu 43:40 dan sudah ditonton 59.555 kali, like 596, dan subscribe 83 ribu.

Gus Izza selalu memberi pengantar dari setiap pengajian dengan meniru kepada abahnya Kyai Imron Jamil dengan melafalkan akhir Surat at- Taubah "laqad jaa akum...\& ayat kursi." Video pertama yang diupload pada 26 april 2017 memang viral sebab sudah lebih dari 2 juta penonton. Isi yang disampaikan oleh Gus Izza adalah terkait pentingnya berdzikir dan beriman. Bagi sebagian orang yang namanya berdzikir tentu melafalkan dan pengagungan kepada Allah dengan mengucap istighfar, subhanallah, Yaa Latif dan sebagainya tetapi orientasi yang disampaikan Gus Izza berdzikir yang selalu membangkitkan semangat keimanan dengan dibuktikan ia mengutip dan menyampaikan isi Q.S alAshr:[1-3]. "Demi masa sesungguhnya manusia itu dalam keadaan yang rugi kecuali orang yang beriman, beramal 
Otoritas Keilmuan Gus Izza Sadewa...hal. 167-182

sholeh, saling nasehat menasehati dalam hal kebenaran dan dalam hal kesabaran."

Dari isi yang disampaikan oleh Gus Izza dengan mengutip ayat al-Qur'an tersebut sebagaimana penuturan Syafi'i (wawancara, 1 Juni 2018) pendengar setianya:

Kalau bagi saya pengajian Gus Izza bukanlah ngaji anak anak kecil pada umumnya namun pengajian ilmu tua (ilmu tasawuf) atau ilmu menata hati. Bahasanya disampaikan ceplas ceplos dengan guyonan yang khas dan lugas kadang-kadang membuat saya berfikir iya sih beriman itu tidak harus sholat akan tetapi juga harus menjaga akhlaq. tapi saya suka ceramahnya, enak didengar dan lucu.

Bahasa yang digunakan oleh Gus Izza juga terkesan santai dan menguasai panggung dengan cukup apik, tidak ada keraguan yang disampaikan di publik seolah olah layak mendapat predikat kyai besar yang sudah kondang dan memiliki beribu jama'ah. Ternyata konten yang disampaikan oleh Gus Izza memberi penilain sendiri bagi yang sering mendengarkan ceramahnya di Youtube. Penilain dan rasa takjub yang tak terkatakan sebab dengan umur masih belia keilmuan tasawufnya cukup kentara.

Video kedua yang dibuat di daerah Jepara diunggah pada tanggal 17 Juli 2018, walaupun tidak terlalu viral sebagaimana video pertama. Dalam segmen video ini Gus Izza membeberkan pentingnya menjadi orang yang "luman" suka memberi karena dengan suka memberi maka Allah akan mudah memberi keberkahan hidup dan ketenangan/kebahagiaan jiwa. Gus Izza menyampaikan ini dengan mengutip ulama sufi terkenal yakni Imam al-Ghazali dalam kitab Bidayah al-Mujtahid, "Yaa ayyuhal haris" wahai orang yang suka memberi. Hal ini sejalan dengan pendapat dari bapak Ismail (wawancara, 2 Juni 2018) :

Saat saya tak sengaja memutar pengajian Guz Izza dan saya dengarkan sambil makan, ada rasa kagum dan heran begitu masih muda dan sudah berilmu dan memahami ilmu rasa. Banyak hal baru yang saya peroleh dari Gus Izza meskipun saya tidak pernah bertemu langsung dengan beliau. Tapi saya yakin Gus Izza itu putra Kyai Imron Jamil bakal menggantikan peran ayahnya yang berilmu tinggi dan luas.

Gus Izza mengutip dari ayat alQur'an mengenai ulama yang patut di ikutin yaitu "Innama yakhsya Allaha min 'ibadi alúlamu" arti sesungguhnya yang hanya takut sama Allah hanya ulama. Ulama menjadi bagian yang penting dalam memberikan pengaruh keilmuan yang tinggi.

Ada dua ulama yang disampaikan oleh Gus Izza yaitu ulama komandan dan ulama informan. Ulama informan itu adalah ulama yang memberi ilmunya Allah kepada orang lain, contoh kyai, guru, dosen, tutor, teacher, guru besar. Sedangkan ulama komandan itu disebut sebagai Wali Mursyid yaitu ulama yang mengatur langkah jalannya hidup untuk menuju kepada Allah, artinya apapun yang dilakukan untuk memperoleh hak bisa bertemu dengan Allah membutuhkan wali mursyid. Wali mursyid dalam pandangan Gus Izza sangat penting dan bagi masyarakat muslim sudah selayaknya ikut dan mencari wali mursyid supaya dalam ibadah tidak hanya sekedar ibadah dhohir, namun ibadah batin menjadi prioritas yang utama sehingga perlu dibimbing oleh wali mursyid.

Dengan lihainya Gus Izza menjelaskan pentingnya mencari wali musryid kamil mukamil. Ada 4 syarat 
mursyid kamil mukammil yaitu punya welas asih (peka sosial) dan punya nüril basyhïrah punya daya kekuatan mengetahui apa yang belum terjadi. Ada cerita yang disampaikan oleh Gus Izza bahwa dari sahabat Nabi Umar dan Abu Bakar, Umar membaca alQur'an dengan sangat keras dan kencang sedangkan Abu Bakar membaca al-Qur'an dengan pelan, lembut dan kecil suaranya. Kedua shahabat ini saling menyalahkan mana yang paling benar. Kemudian datanglah Nabi Muhammad bertanya kepada Umar, "Umar, kenapa kamu membaca al-Qur'an dengan suara yang sangat keras?" lalu Umar menjawab, “ alQur'an itu kitab suci, maka kalau saya membaca dengan suara lantang maka hal yang jelek, batil akan menjadi ikut kecipratan atau terkena imbas baik. Sementara Nabi bertanya kepada Shahabat Abu Bakar, "Abu Bakar, kenapa kamu membaca al-Qur'an dengan suara pelan dan lembut?" lalu Abu Bakar menjawab, “ Kalau saya membaca pelan karena kitab ini terlalu suci, jadi kalau saya membaca dengan keras maka menjadi najis. Kemudian Nabi menjawab kepada Umar begini, "Umar kalau membaca al-Qur'an yang pelan pelan.” Dan menjawab kepada Abu Bakar, “ Kalau membaca al-Qur'an yang keras suaranya." Dari kedua jawaban ini bisa ditarik kesimpulan, bahwa ibadah seseorang itu bukan karena kehendaknya sendiri akan tetapi kehendaknya wali murysid yang mengetahui dengan Nüril Basyhïrah (punya pengetahuan mengetahui isi hatinya seorang murid ulasan ada di (youtube, 21 juni 2018).

Video ketiga yaitu ceramah di surabaya. Isi ceramahnya tidak jauh berbeda dengan isi ceramah yang dilakukan kesatu dan kedua, begitu pula isi ceramah yang dilkukan pada video keempat yaitu mengenai pentingnya tentang wali mursyid bagi siapa saja yang ingin menapaki khazanah perjalanan spiritual dalam ibadah yang sesungguhya kepada Allah. Ibadah yang sesugguhnya ini penting dijalankan demi menuju hakikat kebahagiaan hidup yang sejati.

Video keempat membicarakan tentang ketauhidan. Pentingnya nilai dan aktualitas Tauhid dalam kehidupan sehari hari hari. Tauhid yang disebutkan oleh Gus Izza adalah sebuah kalimah " Laa ilaa ha Illa Allah". Kalimah tauhid tidak hanya sebagai bacaan yang sering dilafalkan seusai shalat berjamaah lima waktu, baik di masjid, musola atau dirumah, akan tetapi dibutuhkan agar menjadi sebuah aktus kehidupan yang nyata dalam keseharian. Setiap muslim yang sering beribadah kepada Allah lima waktu dimasjid bagi Gus Izza belum tentu memiliki tauhid yang mewujud dalam dirinya, sikap dan tindakan. Karena hanya diucapkan lewat mulut secara keras (jahr) tanpa dibarengi dengan pikiran dan daya hati yang kuat saat berzikir pada Allah. Menurut sebuah penjelasan singkat dari Gus Izza, "setiap apapun didunia ini yang bukan Allah itu pasti bukan Allah inilah Tauhid, setiap apapun di dunia ini yang nampak berarti bukan Allah". Memprioritaskan tauhid sebagai laku kehidupan yang nyata perlu dilandasi dengan rasa cinta yang nyata kepada Allah, karena sebagai wujud cintanya seorang hamba kepada Allah maka tidak ada unsur kepentingan. Landasan cinta itu memiliki landasan pasrah total dalam menyembah Allah. Tidak ada tujuan yang lain hanyalah kepada Allah. Komentar para jama'ah.

Masih muda, ilmu agamanya luar biasa publik sepakingnya baGus, mampu menempatkan dirinya di dalam berceramah juga sangat pas...nurut ngaji Gus (Video Sapu Jagad TV 17 juli 2018). 
Otoritas Keilmuan Gus Izza Sadewa...hal. 167-182

PENUTUP

Otoritas yang dibentuk oleh Gus Izza

dari penggalian beberapa analisis penulis, merupakan suatu fenomena baru yang langka, artinya rating dan jumlah video yang ditonton membuat otoritas itu semakin memiliki akar kuat, otoritas yang memiliki kekuatan adalah karena adanya struktur, ideologi, teks dan keilmuwan yang mumpuni. Pertama, Struktur dari beberapa lingkungan dan para guru yang membentuknya terutama KH. Imron Jamil sebagai ayahnya. Kedua, ideologi sufistik membentuk suatu pemahaman yang mendalam dalam cara pandang Gus Izza. Ketiga, hirarki terbentuk dari tradisi keluarga yang dipimpin oleh seorang berwibawa dan kharismatik. hal ini dari ciri khas seorang publik figur mampu bersosial dimasyarkat yang butuh sentuhan rohani, sehingga ini yang mewujudkan tatanan sosial keluarga masyarakat menjadi lebih damai dan harmonis. Keempat, teks menjadi salah satu unsur terpenting sebagai simbol yang merepresentasikan kemiripan keluarga family resemblances di antara komunitas masyarakat muslim di lingkunganya. Keempatnya memberi realitas yang kongkrit dalam membentuk tradisi keilmuwan di dalam keluarga.

Keilmuwan tasawuf yang selalu disampaikan dari setiap isi ceramahanya oleh Gus Izza ini tidak biasa sebagaimana isi ceramah yang disampaikan para dai muda yang lain terutama da'i yang seringkali muncul dikaca TV Indonesia, sehingga nilai keunggulan sebagai pemegang ilmu tasawuf menjadi nilai otoritas yang melekat pada diri Gus Izza. Mungkin umur tidak memungkin melambungkan namanya sebagai seorang kyai atau penceramah, namun kondisi dan situasi inilah ynag kemudian membuat dirinya tampil, bahkan dalam segmen video yang diunggah tidak ada sama sekali keinginan menjadi seorang kyai, akan tetapi atas saran abahnya kalau sudah menjadi apa yang digariskan oleh Allah maka sebagai seorang hamba tidaklah bisa menolak. Akhirnya secara berat hati karena Gus Izza sebagai seorang yang tuduk dan taat kepada orang tua (orangtua seklaiGus gurunya) maka titah dari orang tuanya dilaksanakan.

Otoritas yang dibentuk oleh Gus Izza dari struktur, ideologi, hirarki dan teks. Secara struktur Gus Izza Gus Izza dibesarkan dilingkungan terkenal santri dan kuat tradisi tasawuf, mengingat Kyai Imron Jamil juga seorang mursyid Thariqat Syadzliyah. Kedua secara ideologi yang diikuiti yaitu keyakinan dalam konteks dunia tasawuf yang melingkupi, secara hirarki bahwa Gus Izza tidak lepas dari peran guru gurunya terutama guru dari abahnya yaitu KH. Abdul Jalil Mustaqim Tulungagung konon ilmunya langsung diinstal oleh beliau. Hal ini terbukti tidak sekolah dasar pun beliau menguasai ilmu tawasuf hingga thariqat. Secara teks tentu tidak lepas dari arah isi ceramahanya selalu ada saran dalam membicarakan perkara hati dan pentingnya mencari guru wali mursyid supaya dalam ibadah diberi langah yang tepat bukan ibadah atas dasar nafsu dan kehendaknya diri sendiri.

Jadi otoritas keilmuwan tidak semata mata dilambungkan oleh peran youtube akan tetapi keilmuwan atau isi ceramahnya yang membuat detak kagum para pendengarnya, hal ini terbukti dari beberapa video yang viral pun tidak terlalu banyak yang menonton. Video yang diuplaod pun juga biasa biasa aja. Hanya saja yang paling banyak saat pertama live di Trenggalek dengan sudah ditonton lebih dari 2 juta. Artinya otoritas terletak pada struktur dan ideologi yang membentuknya dengan 
M. Ulil Abshor

dibantu oleh media baru lewat youtube sehingga bisa diakses dan diketahui ilmu yang disampaikan.

\section{DAFTAR PUSTAKA}

A. Campbell, Heidi, ed. (1996). Digital Religion: Understanding Religious Practice in New Media Worlds. London and New York: Routledge.

Amiartuti, (2012). "Peranan Kepemimpinan Dalam Membentuk Perilaku Individu dalam Berorganisasi pada UMKM", dalam Media Mahardika, vol. 11, No, 1 September.

Bertens, K. (1995). Filsafat Barat Abad XX, Yogyakarta: Kanisius.

Burhanuddin, Jajat.(2012). Ulama \& Kekuasaan, Pergumulan Elite Muslim dalam sejarah Indonesia, Jakarta: Mizan Publika.

Carter, April. (1979). Otoritas dan Demokrasi, Jakarta: Rajawali Press.

F. Nisa, Eva. (2018). "Creative and Lucrative Da'wa: The Visual Culture of Instagram amongst Female Muslim Youth in Indonesia", Asiascape: Digital Asia, vol. 5.

https://materiips.com/contoh-struktursosial. Diakses pada tanggal 8 juni 2018.

Hansen. P. George, (2001), Max Weber Charisma and The Disenchanment of The World, t,p, Xlibris.

Hajar, Ibnu. (2018). “ Youtube Sebagai Sarana Komunikasi Dakwah di Kota Makassar", dalam Jurnal alkhitabah, (5:2).

Jabir al-"Alwani, Taha. The Ethics of disagreement in Islam, Ed. A.S.alShaikh Ali. USA: The International Institute of Islamic Thought.
Loomis, Charles P. (1960), Social system: Essay on their Persistence and Change, New York: Van Nostrand INC.

Manovich, Lev. (2003). "Introduction of New Media", dalam The New Media Reader, ed. Noah Wardip-Fruin and Nick Montfort. Cambridge and London: MIT Press.

Muhammad, Hasyim. (2000). Maqamat dan Ahwal dalam Tradisi Tasawuf dan Psikologi Humanistik Abraham $\mathrm{H}$. Maslow, Yogyakarta: Psutaka Pelajar.

Profil pondok pesantren Kyai Mojo Jombang diakses tanggal 27 Mei 2018

Purwasih Joan, Gita, dkk, (2009). Ensiklopedi Sosiologi Struktur Sosial. Klaten: PT Cempaka Putih.

Rodee, C.C, dkk, (1983). Pengantar Ilmu Politik, terj. Zulkifli Hamid, Jakarta: Raja Grafindo Persada.

Rusli, Ris'an. (2013). Taswuf dan Tarekat:

Studi Pemikiran dan Pengalaman para Sufi, Jakarat: Rajawali Pers.

Satrapratedja, (2003). Ide Ide Menerobos. Yogyakarta: Kanisius.

Setiawan, Rudy, (2013). "Kekuatan New Media Dalam Membentuk Budaya Populer Di Indonesia", dalam Ilmu Komunikasi, Volume 1, Nomor 2.

Strinati, Dominic. (2007). Populer Culture. Bandung: Penerbit Jejak.

Stellarosa, Sandra Jasmine Firyal \& Andre Ikhsano, Yolanda. (2018). "Pemanfaatan Youtube Sebagai Sarana Transformasi Majalah Highend", dalam Jurnal Lugas, (2:2).

Tim Penyusun, (2008). Kamus Bahasa Indonesia. Jakarta: Pusat Bahasa Depatemen Pendidikan Nasional. 
Otoritas Keilmuan Gus Izza Sadewa...hal. 167-182

Kusuma Dewi, Subkhani. (2016). "Otoritas

Umat Islam", dalam Jurnal Living

Teks Sebagai Pusat dari Praktik

Hadis, (1:1). 